CZASOPISMO INŻYNIERII LĄDOWEJ, ŚRODOWISKA I ARCHITEKTURY JOURNAL OF CIVIL ENGINEERING, ENVIRONMENT AND ARCHITECTURE JCEEA, t. XXXIII, z. 63 (2/I/16), kwiecień-czerwiec 2016, s. 321-328

\author{
Magdalena SZPYTMA ${ }^{1}$ \\ Adam RYBKA ${ }^{2}$
}

\title{
ECOLOGICAL IDEAS IN POLISH ARCHITECTURE - ENVIRONMENTAL IMPACT
}

\begin{abstract}
Solutions in the field of ecological architecture appear more and more often in Poland. There are two approaches to eco-design: high-tech and low-tech. High-tech focuses on the use of the latest technological solvings. These means are often used in newly designed commercial buildings, such as the first Polish office building which uses passive technology, built in Katowice, in Euro-Centrum Science and Technology Park. It is intended especially for companies focusing on energy observance issues. Low-tech is usually used in small-scale buildings (for example a cottage in Jartypory village), and is focused on the use of inexpensive, traditional technologies and the daily conscious management of natural resources. Thinking about the impact on the environment and principles of sustainable development is also present in urban planning. In Siewierz, near Katowice, Poland's first ecovillage is being built, with full infrastructure, high-quality residential buildings, shops, offices and hotels. The range of applied solutions will allow residents for the economical exploitation of these buildings.
\end{abstract}

Keywords: sustainable architecture, housing, office building, town

\section{Introduction}

Issues of ecology in architecture, as well as within the wider construction sector, are part of a broad trend of sustainable development. „In the period of the environmental threat and energy crises, sustainable development has become a basic strategy of actions in spatial planning. Architecture and building engineering are the largest economic sector in terms of economy and the flow of raw materials. The majority of capital, both financial and natural is invested in structures. The role of architecture and construction in the creation of sustainable de-

\footnotetext{
${ }^{1}$ Autor do korespondencji / corresponding author: Magdalena Szpytma, Rzeszów University of Technology, Faculty of Civil and Environmental Engineering and Architecture, Department of Town Planning and Architecture, al. Powstańców Warszawy 12, 35-959 Rzeszów, tel. 177432142, mszpytma@prz.edu.pl

2 Adam Rybka, Rzeszów University of Technology, Faculty of Civil and Environmental Engineering and Architecture, Department of Town Planning and Architecture, al. Powstańców Warszawy 12, 35-959 Rzeszów, tel. 178651624, akbyr@ prz.edu.pl
} 
velopment is important"[1]. A big impact of construction and architectural sector on the environment is indicated by Anna Bać in the article „Idea of sustainability and its chosen manifestations". Due to the territorial expansion of cities, industrial development and infrastructure, construction and architectural sector ranks at $42 \%$ of the whole energy consumption and $35 \%$ of greenhouse gas emissions [2]. The concept of sustainable development was defined for the first time in 1988. In the Brundtland Report as ,,a development that is able to meet the needs of the present without compromising the ability of future generations to satisfy their needs"[3],[4]. The report concluded issues of social, economic, cultural and environmental problems, as well as identified potential solutions. Hence the concept of the so-called 3 pillars of sustainability, which is a balanced, sustainable development in the field of society, economy and ecology. Ecological ideas are one of the pillars of sustainable development. A. Baranowski in his groundbreaking book "Sustainable design in architecture," points to the convergence of ecological design ideas with the concept of sustainable development. He indicates the formation of a new paradigm of architecture, based on the ideas of environmental and contextualism, where the priority is to develop the environmentally friendly spaces [5]. On the other hand Marchwiński J. and Zielonko-Jung $\mathrm{K}$. pay attention to the directions of ecological research in architecture, which according to Brian Edwards should derive patterns of cultures other than Western consumer culture. The principles of this search should be based on demands: sufficiency, appropriate management, social responsibility and 'spirituality' of the project [3], [6].

There are two different ways of achieving the objectives and demands of ecological architecture. At one extreme are the directions embedded in tradition, based on a close relationship with nature, the local climate and culture. Other group includes solutions based on technological solutions, which undergoing the process of continuous improvement. The below mentioned examples show that ecology may be diverse and adaptable to the scale of a building. These examples prove that pro-ecological ideas are applicable in Polish conditions.

\section{Mini eco scale - housing}

In 2000, in the village of Jartypory (the central-east Poland) a cottage was built in the low-tech style that was limited to minimizing construction and operation costs without applying, still quite expensive, advanced technology. Also, the building traditions of this indigent region were employed.

The house is small (just over $100 \mathrm{~m}^{2}$ ), compact in form, with one, modest sanitation assembly. The use of thermal energy is limited by proper floor plan design - the rooms are open to the south, east and west and the house is sheltered from wind by a slope on its north side. This was an easy way to reduce heat loss and profit by passive solar heating. A buffer was used as well to prevent from extensive air exchange. The building is composed of simple materials, 
not requiring great energy expenditure in the production process. (This is the element of pro-ecological thinking on a larger scale.) The house is made of limeplaster bricks, gypsum and insulated with cellulose wool made up of wastepaper. It is established on a waste-land, but almost the whole parcel is biologically active (the green roof tops it all).

Rainwater is reused for household purposes, and drinking water is purified by a constructed wetland, a low-tech solution, which works like a natural one. Wastewater is treated within the parcel. Energy consumption necessary for artificial lightning is reduced to minimum by providing daylight access. Energy consumption needed for air-conditioning is decreased by applying natural ventilation. One of the few high-tech components is a catalytic converter on a modern wood boiler [7].

Eco-friendliness of the project is not confined to architecture. It could be noticed in the attitude and way of life of the investors, who decided to do part of their job at home, which resulted in reduction of exhaust emission and macro improvement of air quality. It seems that this deep awareness and civil responsibility of the investors is the main cause of the project's success. They were willing to limit their own needs and submit to nature. This project shows that one of the most important issues is being aware of one's real necessities.

\section{Medium eco scale - office building}

In order to include big, public buildings in the trend of sustainable development, more advanced technologies must be used [8]. A good and current example is an office building constructed within Euro-Centrum Science and Technology Park in Katowice - a completely passive building of $6335 \mathrm{~m}^{2}$ space.

The construction began in August 2011 as part of the project "Creating Euro-Centrum Science and Technology Park - the development and application of new technologies in the field of energy and its renewable resources observance". Activity of the Park focuses on the matters of energy observance in buildings and the development of energy-saving technologies. The Park was established in 2007 and consists mainly of modern business and research infrastructure. It combines business and scientific activities in a comprehensive way. Owing to laboratory background, financial support and instant access to knowledge and results of the newest trade research, it presents as an ideal location for technological companies. What provides an excellent scientific background and a platform for information exchange is co-operation with research and development centres such as AGH University of Science and Technology, the University of Silesia, Silesian University of Technology, Czestochowa University of Technology, the Institute for Chemical Processing of Coal in Zabrze and the Institute of Electron Technology in Warsaw. The new building will serve the expansion of the Park's technical infrastructure and creation of first Silesian laboratories for developing energy-saving technologies and renewable energy resources. (Fig. 1). 


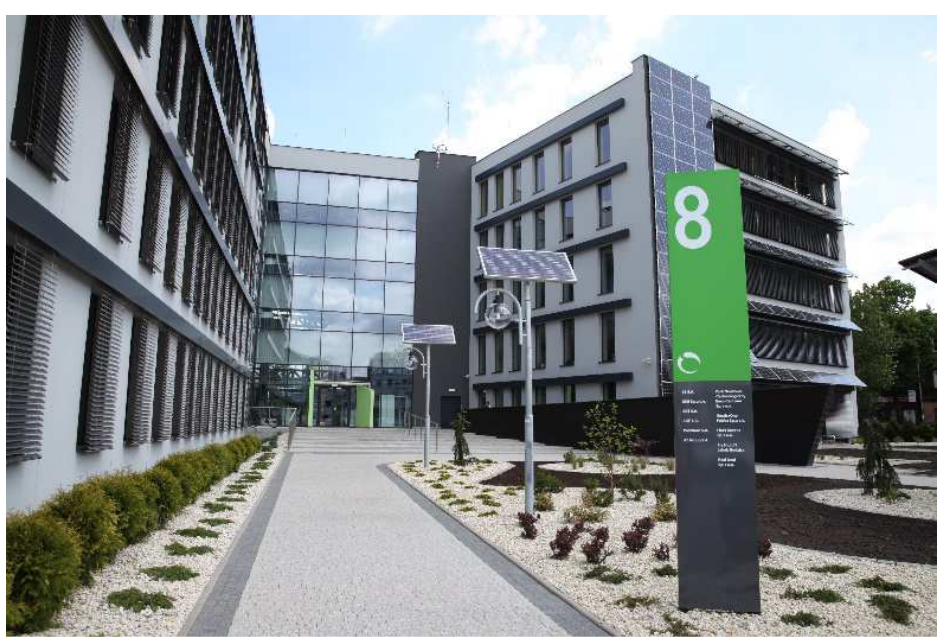

Rys. 1. Pasywny budynek biurowy - Euro-Centrum Park Przemysłowy w Katowicach, wg [9]

Fig. 1. Passive office building - Euro-Centrum Science and Technology Park in Katowice, acc to [9]

The building was designed by an architectural firm Projekt Grupa Sławomir Kostur. It is intended for technological companies engaged in research, development and innovation work, especially in the field of renewable energy resources. Due to the ecological and energy-saving solutions, this office block will meet all requirements of a passive building. The proposed technologies will allow to save up to $2 / 3$ of standard energy consumption. The brain of the building will be BMS, Building Management System, responsible for appliances operation. By means of sensors, it will control the temperature and decide about additional heating or cooling. It will be integrated with roller shutters. After working hours, all elements of ventilation will be shut in order to save heat accumulated inside the building. A heat pump will be responsible for heating the building. With help of geothermal wells, heat obtained from the ground will be used for heating the water, which will operate CCTC, Concrete Core Tempering system. CCTC system uses the rule of heat accumulation. In summer, partitions are absorbing the heat excess, and in winter, they insulate. Inside ceilings, which are $30 \mathrm{~cm}$ thick, there will be pipes with the heating or cooling water flowing through. CCTC system will be supported by a mechanical ventilation heat recovery. The heat recovery ventilation, installed on the roof, will be able to regain up to $75 \%$ of thermal energy from the air pumped out in winter. In summer, hot air from the outside will be refrigerated by chilled water in an air handling unit. The roller shutters, equipped with insolation sensors and own management system, will close or open according to the weather conditions. Solar collectors, installed on the roof, will be used to transform solar radiation into heat, which can be transmitted by gas or liquid. Electricity will be also obtained by means of 
solar cells. All used technologies will allow to reduce the demand on energy necessary for heating the space from $120 \mathrm{kWh} / \mathrm{m}^{2} /$ year to $15 \mathrm{kWh} / \mathrm{m}^{2} /$ year.

Within the same project another building of over $738 \mathrm{~m}^{2}$ space is being revitalised. It will become the premises of the Centre for Testing Solar Systems and Modern Heating Technologies Training Centre. The use of all the latest technologies, which allow for the economical energy management, will enable the development of new techniques. Specialised laboratories will permit the tests of collectors and solar systems (the so-called artificial sunlight or solar simulator), as well as devices resistance to thermal shock and water. Specialised trainings will be organised for the fitters of solar collectors, heat pumps, ventilation systems and solid fuel boilers [10].

The principles of sustainable development are crucial to the Park. (The function of the Park is inseparably bound with the idea.) And as the real elements of the project, that is the buildings, originate from these principles, they become the showcase of the idea and part of the philosophy based on the practical implementation of conducted research. Obviously, this serves the purpose of establishing the project's brand under the banners of ecology. However, the idea itself is so noble that even marketing does not diminish its value.

\section{Maxi eco scale - new urban district}

The problem of investments effect on the environment and sustainable development rules appears also in town-planning. Near Katowice, in Siewierz, the first Polish ecological district is being built from the scratch. The area of the investment covers 120 ha in the vicinity of the Przeczycko-Siewierski Reservoir. Due to the very good road connection with the Silesian conurbation, this location has a great potential to become an ideal place to live for people who appreciate being in touch with nature and professionally active at the same time.

The site topography and its landscape qualities are valuable features. The project of the town rests on the principles of sustainable development, combining the respects towards environment, public needs and economic efficiency. It was designed by an international team of town-planners, presided by Maciej Mycielski. Two-week workshops were organised with experts, local community, the representatives of local authorities and an investor, during which the form of the future investment was discussed [11].

The basic idea of the project was to respect existing landscape and preserve its value. The concept of eco-town refers to the guidelines of a garden city, characterised by low buildings and vast green belts intended for recreation. The plan of the town was tailored to fit the site topography. The hilly lay of land and a slope towards a lake affect parcel's landscape attractiveness. Additional asset is a long shoreline overgrown with verdure (Fig. 2). 


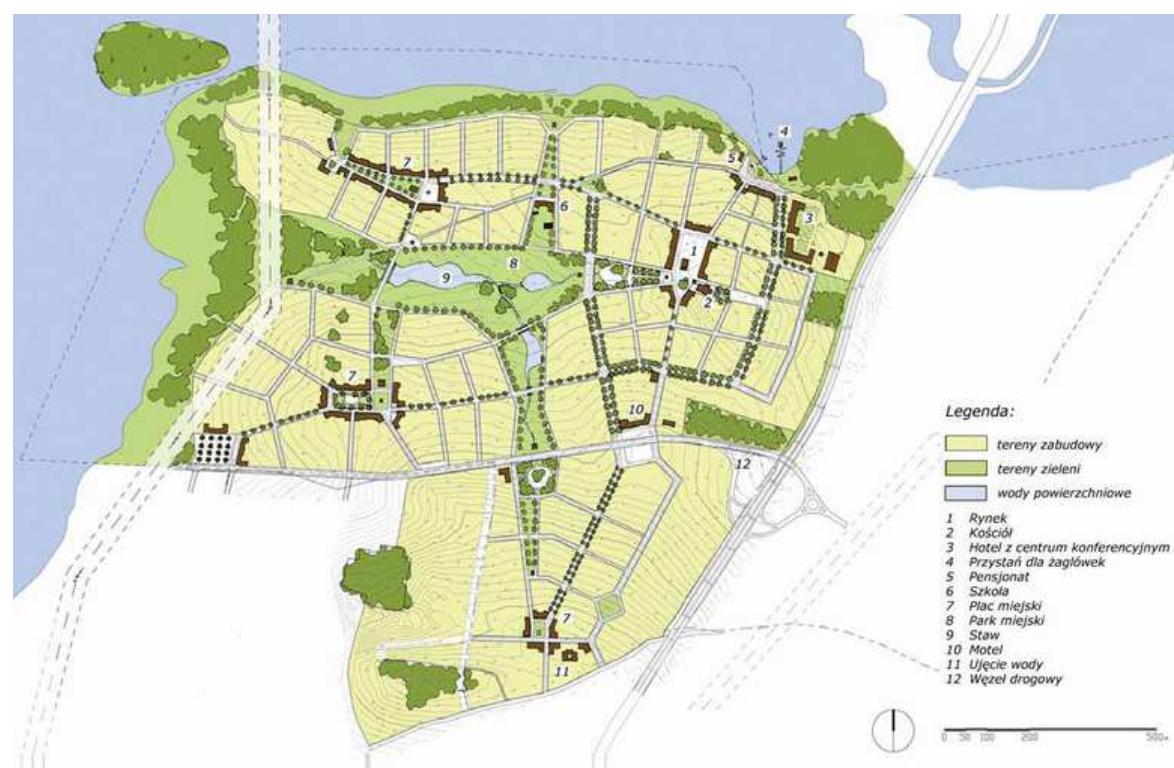

Rys. 2. Ekologiczna dzielnica Siewierza - plan, wg [12]

Fig. 2. Ecological district of Siewierz - plan, acc to [12]

The area was divided into a few accommodation units, diversified in the respect of character and building scale, and located around town squares. Apart from housing function: detached, semi-detached, terraced and apartment houses, there will be a business zone, too, with certified office blocks, service space, a hotel and a conference centre. As usual, a market place will fulfil the cultural function. The market place will be the "source" of a park with the system of ponds and pools, located in a centrally situated valley. The naturally shaped shoreline, expanded upon a pier, a little marina, an amphitheatre and a beach will make a great space for resident's recreation.

In co-operation with experts on environmental protection, modern technologies and sustainable town-planning, detailed solutions were elaborated, which ensure economical energy management within the town and particular buildings. The implementation of modern solutions is planned, which will guarantee high energetic efficiency, low carbon dioxide emission and rational water resources management. In order to attain assumed result, the construction of a combined heat and power plant is slated; it will use natural gas to produce heat and electricity, and, consequently, it will provide cheaper energy and central heating for the office complex and apartment houses. Modern methods of obtaining thermal energy, such as heat pumps, will allow for reduction of $\mathrm{CO}_{2}$ emission and savings during the exploitation. The high acreage of green belts will be watered by means of recycled rainwater. 
Each accommodation unit will be self-sufficient thanks to own production of electricity and heat as well as partial wastewater treatment. Solar cells, wind turbines and engine-generators running on biofuel will be the source of electric current. Solar collectors and fireplace units will be used to obtain hot water. Rainwater cisterns, plant filters and pumping stations will allow for rational water resources management. Sales department will be established, where all information will be provided by an expert on ecology and sustainable development. Every client will be given an eco-training on how to decorate and use an apartment so that it is completely eco-friendly [11][12].

The given example applies to long-term actions designed for at least several years. The fact of creating an accommodation project, which is not just adapting to the existing eco-friendly trends, but which crux are the principles of sustainable development, is meaningful. It is a brand new quality and it opens new possibilities for better solutions. Also, the emphasis put on the education of residents is significant. Undoubtedly, this will be the key element of the project's success in terms of ecology. If the investment is successful, it will be an extraordinary achievement, which, and this is most likely, will be the point of reference for other town-planning projects based on similar guidelines.

\section{Conclusions}

Ensuring environmental protection in accordance with the principles of sustainable development is stipulated in the Polish Constitution. Until recently, the short-sightedly perceived economic matters have been outbalancing the longterm evaluation of effects buildings have on the environment. Nowadays, this subject is being considered with proper attention and ecological questions are more often raised not only by the architects, but also by the investors. Marchwicki J. and Zielonko-Jung K indicates the essence of local factor in sustainable design. "Eco-friendly architecture should not be considered through the prism of physiognomic characteristics of the buildings (...), but more in terms of the objectives and the associated demands that are imposed on it. The diversity of ways of their implementation, which is the resultant of social, cultural, economic, environmental and many others factors, makes eco-friendly architecture seen as breaking the anonymity of Western culture in building construction"[3]. The presented examples show that within Polish architecture quite bold and frequent solutions (on a very diversified scale) are founded on the ideas of environmental protection. They show that ecology may be profitable, diverse and adaptable to the scale of a building. Today, the town-planning scale seems to be attainable. In the future, it could change the effect we have on the environment globally, although, it all begins with the change of a way of thinking, and only full awareness of being responsible for the environment, for the sake of future generations, can be the key factor of change. 


\title{
Bibliography
}

[1] Kamionka. L.: Standardy architektury zrównoważonej jako istoty czynnik miasta oszczędnego na przykładzie wybranych programów certyfikacyjnych, Czasopismo Techniczne, 6-A 2010, Z. 14, R. 107, pp. 27.

[2] Bać A.: Idea zrównoważenia i jej wybrane przejawy, Architectus, 2014, 2(38), pp. 4.

[3] Marchwicki J., Zielonko-Jung K.: Współczesna architektura proekologiczna, Wydawnictwo Naukowe PWN, Warszawa 2012, pp. 2, 13.

[4] Jones D.L.: Architecture and Environment. Bioclimatic Building Design, Laurence King, London 1998.

[5] Baranowski A.: Projektowanie zrównoważone w architekturze, Wydawnictwo Politechniki Gdańskiej, Gdańsk, 1998 pp.67-68.

[6] Edwards B.: Sustainable Architecture, Architectural Design, vol. 71, 04.2001.

[7] Śmiechowski D.: Architektura proekologiczna z zastosowaniem podejścia niskotechnologicznego (low-tech), Architektura 4(187)/2010.

[8] Intelligent Building Technology and Multimedia Management IBTMM, Kraków, 2015, http://ibtmm.pl/, \{accessed 17.02.2016 r.\}.

[9] http://www.ligocka103.pl/grupa/parku-naukowo-technologiczny, \{access 19.02.2016\}.

[10] http://euro-centrum.com.pl/park-naukowo-technologiczny, \{access 16.02.2016\}.

[11] http://www.siewierzjeziorna.pl/, \{access 15.02.2016 r. $\}$.

[12] Czyżewski P.: ttp://koalicjaklimatyczna.org/lang/pl/page/materialy_konferencyjne/ $\mathrm{id} / 8 /$ file/37/option/save, \{access 28.02.2016 r. .

\section{IDEE EKOLOGICZNE W POLSKIEJ ARCHITEKTURZE - WPEYW ŚRODOWISKOWY}

\begin{abstract}
Streszczenie
Proekologiczne rozwiązania architektoniczne stają się w Polsce coraz bardziej powszechne. Wyodrębnić dwa podejścia do tematu projektowania ekologicznego - high-tech i low-tech. Hightech skupia się na wykorzystywaniu najnowszych rozwiązań technologicznych - tego typu rozwiązania stosowane są często w nowoprojektowanych budynkach komercyjnych. Dobrze pokazuje to przykład biurowego budynku pasywnego w Katowickim Parku Przemysłowym - EuroCentrum. Rozwiązania low-tech - stosowane są najczęściej w budynkach o małej skali (przykład domu w miejscowości Jartypory), skupiają się na wykorzystaniu niedrogich, tradycyjnych technologii i codziennego świadomego gospodarowania zasobami naturalnymi. Troska o środowisko naturalne jest również widoczna w projektach urbanistycznych. W Katowicach powstaje pierwsza w Polsce ekologiczna dzielnica mieszkaniowa, wyposażona w pełną infrastrukturę usługową oraz proekologiczne rozwiązania budynków.
\end{abstract}

Słowa kluczowe: architektura zrównoważona, budownictwo mieszkalne, budynki biurowe, miasta

Przestano do redakcji: 5.03.2016 $r$.

Przyjęto do druku:1.06.2016 $\mathrm{r}$.

DOI: $10.7862 /$ rb.2016.133 